\title{
Los retos actuales de la izquierda en Centroamérica: ensayo a partir de la obra de Boaventura de Sousa Santos
}

Juan Hernández Pico, S.J. Departamento de Teología Universidad Centroamericana "José Simeón Cañas"

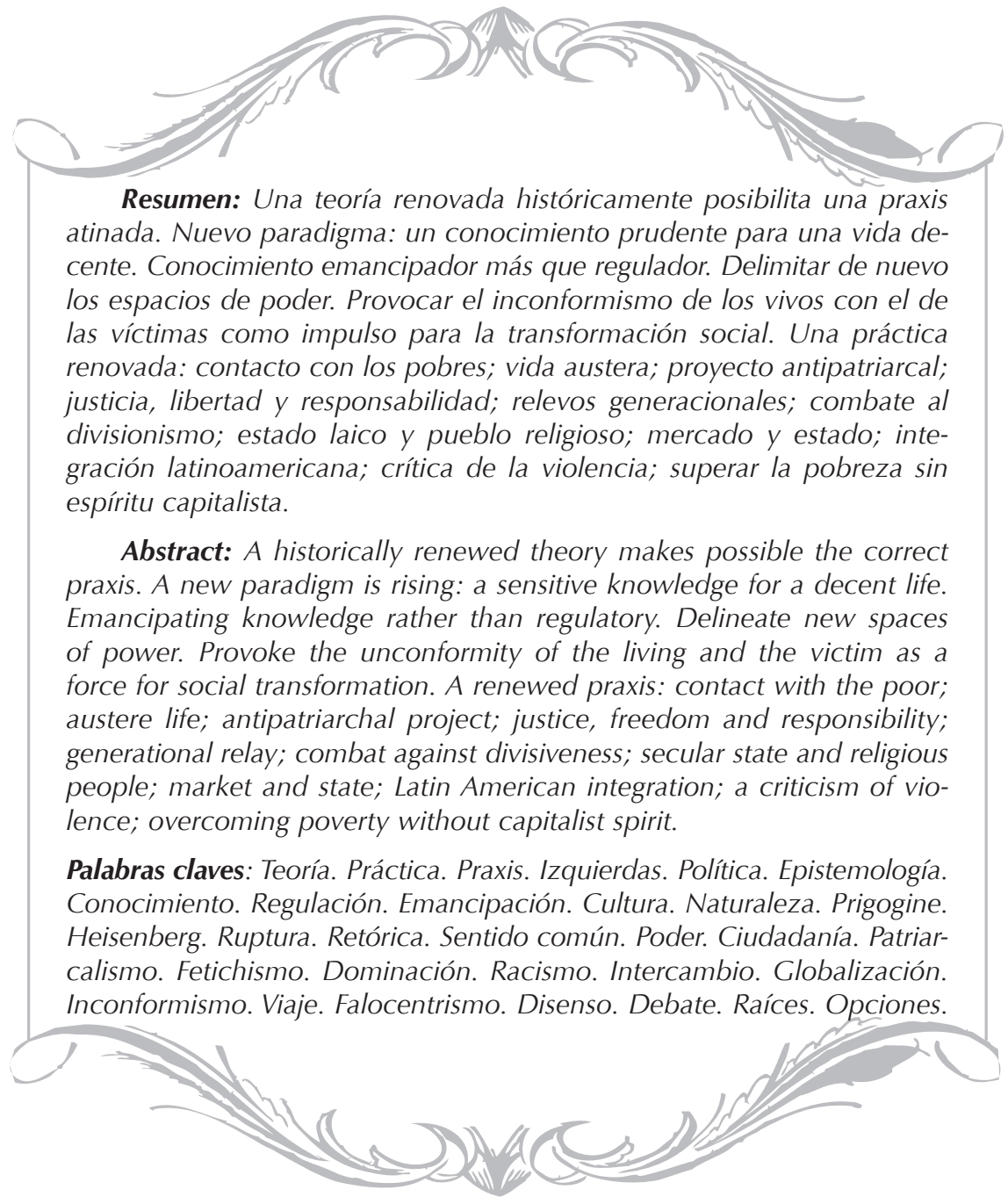


Voy a proponer en este ensayo 12 retos, si bien creo que el primero (La renovación de la teoría para una praxis adecuada) y el duodécimo (La lucha contra la pobreza), además de la conclusión, que tiene que ver con todos, son los más importantes. He dedicado mucho más espacio al primer reto, la renovación de la teoría, porque creo que es en ese campo donde las izquierdas son —o tal vez somos - más repetitivas, donde la historia del socialismo realmente existente ha ayudado poco a afrontar la construcción de la historia contando con las condiciones que otras izquierdas, ya pasadas, han legado.

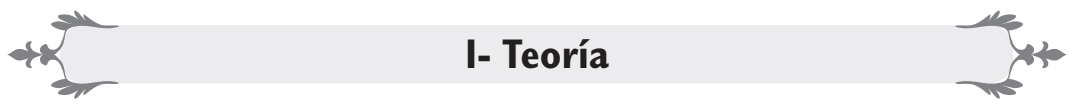

\section{Producir una teoría} revolucionaria autóctona $o$ apropiársela críticamente: hacer una verdadera crítica de nuestra razón indolente.

Sin una teoría acertada y que sepa renovarse según la marcha de la historia, no es posible una práctica política acertada, y por lo tanto es imposible una praxis humana, humanizante y por eso mismo eficaz.

Esa teoría la podemos encontrar en el aporte de varios autores que rompen esquemas. Uno de ellos podría ser David Schweickart y su libro Más allá del capitalismo. ${ }^{1}$ Otro, Robert Fossaert, quien culminó su serie de ocho libros sobre la sociedad con el último sobre El porvenir del socialismo. ${ }^{2}$ Manuel Castells nos ha introducido también con fuerte novedad a las posibilidades de La era de la información. ${ }^{3}$ Evelina Dagnino ha escrito, en colaboración con otros dos autores, La disputa por la construcción de la democracia en América Latina. ${ }^{4}$
Voy a escribir, en cambio -muy por encima ciertamente pero intentando apropiarme lo que de él extracto- sobre la obra de Boaventura de Sousa Santos, que nació en 1940 y piensa lo que llama "un sistema mundial en transición (SMET)".

Este científico social portugués, educado en Coimbra, Berlín y Yale, y en alianza profunda con el Foro Social Mundial, es talvez uno de los más creativos hoy en su campo. Adopta una opción post-moderna de oposición, en cuanto contrapuesta a una opción post-moderna de celebración (la propia de Lyotard, Beaudrillard, Rorty y Vattimo, aunque cada uno sea muy distinto del otro). Ya el título de uno de sus libros principales nos dice mucho sobre sus intenciones: Crítica de la razón indolente. Contra el desperdicio de la experiencia. Las preguntas que se hacen a veces a conferenciantes con fama de izquierdistas, ¿no nos hablan precisamente de la razón indolente o perezosa?: “¿Es usted revolucionario? ¿Es usted marxista-leninista?". 
Uno de los puntos más importantes en que el marxismo deja de ser crítica de la economía política y se convierte en ideología es la infalible dirección de la historia hacia el comunismo. La historia, precisamente, nos ha mostrado que en su decurso o dirección no hay seguridad ninguna de los resultados y sí, en cambio, reversiones y cambios imprevisibles, como los del año 1981, con la introducción en el socialismo chino del capitalismo por obra de la política de Deng Chiaoping; del 9 de noviembre de 1989, con la caída del Muro de Berlín; de diciembre de 1991, con la disolución de la Unión Soviética; y del 13 de noviembre de 2008, con la quiebra del enorme banco Lehman Brothers, preludio de la primera gran crisis de la globalización. No hay determinismo en la historia. La historia no avanza indefectiblemente, sino que nosotros hacemos la historia - como Marx decía- sobre la base del legado histórico de nuestros antepasados y predecesores, con nuestros propios aciertos y equivocaciones.

\subsection{La crisis epistemológica del paradigma dominante}

El punto de partida del pensamiento de Santos es lo que considera como la crisis epistemológica del paradigma dominante: primero, en una macro dimensión, por obra de la teoría de la relatividad de Einstein, que acaba con el tiempo y el espacio absolutos de Newton; segundo, en un micro nivel, como consecuencia de la mecánica cuántica y del principio de incertidumbre de Heisenberg, que nos dice que solo conocemos de lo real nuestra intervención en él cuando lo observamos o investigamos; tercero, por la relativización del rigor del instrumento matemático con el que se expresan las leyes de la naturaleza, según los teoremas de Gödel; cuarto, por las investigaciones del físico-químico Ilya Prigogine, quien teoriza que en sistemas abiertos (es decir, sistemas que funcionan en los márgenes de la estabilidad), se crean situaciones de bifurcación donde un flujo mínimo de energía puede conducir a un estado nuevo:

La importancia de esta teoría reside en la nueva concepción de la materia y de la naturaleza... difícilmente compaginable con la que heredamos de la física clásica. En vez de eternidad, tenemos la historia; en vez de determinismo, la imprevisibilidad; en vez del mecanicismo, la interpenetración, la espontaneidad y la auto-organización; en vez de reversibilidad, la irreversibilidad y la evolución; en vez del orden, el desorden; en vez de la necesidad, la creatividad y el accidente... Lo más importante de esta teoría está en que... forma parte de un movimiento convergente, pujante..., que atraviesa las diferentes ciencias de la naturaleza e 
incluso las ciencias sociales... Ha propiciado una profunda reflexión epistemológica que caracteriza ejemplarmente la situación intelectual del tiempo presente. ${ }^{5}$

Piensa Santos que "el conocimiento científico moderno es un conocimiento desencantado y triste que transforma la naturaleza en un autómata ${ }^{6}$ o, como dice Prigogine, en un interlocutor terriblemente estúpido". Es importante, para entenderlo, que cuando Santos escribe "moderno" se está refiriendo a la modernidad optimista del siglo
XIX, la creadora del imperialismo y de la imaginación de posibilidades sin fronteras para la felicidad de los dueños del mundo. Él, en cambio, como veremos, trabaja desde una posmodernidad "de oposición" que critica tanto al optimismo del mercado como al de la historia. Cree Santos también que...

El rigor científico, en tanto que fundado en el rigor matemático, es un rigor que cuantifica y que, al cuantificar, descualifica..., al objetivar los fenómenos, los objetualiza y los degrada..., al caracterizar los fenómenos, los caricaturiza..., al afirmar la personalidad del científico, destruye la personalidad de la naturaleza... La resonancia de los éxitos de la intervención tecnológica esconde los límites de nuestra comprensión del mundo y reprime la pregunta sobre el valor humano de un afán científico así concebido...

\subsection{Emerge un nuevo paradigma: un conocimiento prudente para una vida decente}

Santos piensa que estamos observando la emergencia de un nuevo paradigma. Pero, "cuando hablamos de futuro..., lo que de él decimos procede de una síntesis personal que reside" —en su caso"en la imaginación sociológica". Santos va a hablar del paradigma de un conocimiento prudente —un paradigma científico- para una vida decente —un paradigma social- De los tres principios de la modernidad — mercado, Estado y comunidad- en el campo de la regulación, cree él que "el utopismo automático de la ciencia" ha colonizado al mercado y al Estado, pero que, al contrario, el principio "de comunidad se resistió a ser totalmente cooptado" por aquél. "Las virtualidades epistemológicas del principio de comunidad" se encuentran en "dos de sus dimensiones: la participación y la solidaridad". La participación fue colonizada al intentar — sin lograrlo- reducírsela a "la esfera política (ciudadanía y democracia representativa)". La solidaridad fue colonizada de forma incompleta "a 
través de las políticas sociales del Estado-Providencia" en los países capitalistas desarrollados. Pero en la mayoría de los Estados-nación es la "sociedad-providencia... la forma dominante de la solidaridad".

Si del pilar modernizador de la regulación pasamos al pilar modernizador de la emancipación, encontramos que "la racionalidad estético-expresiva... resistió mejor" que "la racionalidad moral-práctica" a la invasión de "la racionalidad cognitivo-instrumental y performativo-utilitaria" y a su cooptación por estas. La dimensión de placer y juego, la de autoría — constructiva o deconstructiva- y la de artefactualidad discursiva -la intención argumentativa o retórica con que se crean las obras de arte- pertenecen a la racionalidad estético-expresiva y la convierten en otro potencial epistemológico emancipador. Piensa así Santos que "solo a partir de la modernidad es posible trascender la modernidad", y que el principio de comunidad y la racionalidad estético-expresiva son... las representaciones más inacabadas de la modernidad occidental". Por ello "debe darse prioridad al análisis de sus potencialidades epistemológicas".

\subsection{Preeminencia del conocimiento regulador sobre el emancipador en la Ilustración}

Antes de seguir adelante, traduzcamos a ejemplos concretos la marcha de la historia dentro del paradigma cultural de la modernidad.

La modernidad cultural estalló políticamente en la Revolución Francesa. Su lema - "libertad, igualdad, fraternidad" - se ha traducido socialmente en términos reguladores en el Terror de Robespierre y sus compañeros jacobinos, en las guerras imperiales de Napoleón, en el nuevo colonialismo europeo, del cual Leopoldo II de Bélgica fue un prototipo impresionante de imperialista negociante: explotando su colonia del Congo, produjo en unas décadas 11 millones de muertos en la búsqueda de las maderas nobles (caoba, ébano, teca) y de minerales preciosos o estratégicos (diamantes, oro, cobre). Las bombas nucleares sobre Hiroshima y Nagasaki son otros ejemplos del impulso regulador de la modernidad, presuntamente para asegurar la libertad. Y más en la vida cotidiana, el mantenimiento del trabajo esclavo, de salarios bajos y las represiones de las huelgas obreras, y la negación del voto a la mujer por más de un siglo después de la Revolución Francesa. Pero también la dictadura del proletariado en la URSS, con los incontables millones de muertos para imponer la economía colectiva a los campesinos rusos o para fundar el modo de producción concentracionario en los campos de trabajo forzoso, o los miles de muertos entre los camaradas mismos para asegurar el poder único del "padrecito" Stalin. Y, también socialmente, 
en términos emancipadores, en las revoluciones americanas por la independencia, en la emancipación de los esclavos, en la consecución y extensión del voto para las mujeres y en general de los derechos de las mujeres, en la organización libre de sindicatos, en la proclamación de los derechos humanos, en la lucha contra la tortura, en el indomable pacifismo libertador de Ghandi, en la lucha original de los cubanos liderada por Fidel Castro, y en la lucha de los años 80 de los sandinistas en Nicaragua, en las luchas de independencia de los países africanos $-y$ especialmente en la de Nelson Mandela- y en la conversión de una parte importante de la Iglesia católica a los pobres. Lo que es aquí importante es la ruptura epistemológica: la manera de mirar y valorar todos estos acontecimientos desde el punto de vista de los de abajo

El objetivo será "restablecer las energías emancipadoras que la modernidad ha dejado transformar en hybris reguladora". No para encontrar otro equilibrio, sino "un desequilibrio dinámico que tienda a la emancipación". Santos afirma con contundencia: "Si la postmodernidad de oposición significa algo, es justamente ese desequilibrio dinámico... a favor de la emancipación" (SC, pp. 82-86).

Si solo a partir de la modernidad es posible trascenderla, es crucial asumir que "el paradigma de la modernidad contiene" tanto "el conocimiento-emancipación" como "el conocimiento-regulación". Santos sugiere que el primero "va desde un estado de ignorancia que" designa "como colonialismo, a un estado de saber que" designa "como solidaridad"; mientras que en el segundo, la ignorancia — "caos" - se dirige a otro tipo de saber - "orden" - . Ahora bien, el "desequilibrio a favor del conocimiento-regulación" Ilevó a recodificar la solidaridad como caos y el colonialismo como orden. De esta situación "urge salir" transformando "la solidaridad en la forma hegemónica de saber", y aceptando "un cierto nivel de caos procedente de la negligencia relativa del conocimiento-regulación".

Santos piensa que esto nos ha de llevar a "dos compromisos epistemológicos...: reafirmar el caos como forma de saber y no de ignorancia", haciendo que el orden coexista con el caos - como ya sucede en las teorías científicas de Prigogine y otros-, y revalorizar "la solidaridad como forma de saber". La primera estrategia nos conduce hacia "un conocimiento prudente" que sospeche "de la capacidad de la acción... (control de las causas)" y de su "capacidad de previsión (control de las consecuencias)". Santos añade que "la prudencia", como "actitud epistemológica... es de difícil ejecución porque... sólo sabemos lo que está en juego cuando ya está... en juego". Por ello, es preciso privilegiar la indagación sobre las consecuencias 
negativas de la compleja praxis tecnológica y "asumir ante ellas... una cierta 'hermenéutica de sospecha', en términos de Ricoeur...: las consecuencias negativas dudosas, pero posibles, deben ser tenidas como si fueran ciertas".

Esto nos lleva a contraponernos al "utopismo automático de la tecnología", ${ }^{8}$ aceptando como "acto de coraje" el "tener miedo" de él. ${ }^{9}$ Por otro lado, "la solidaridad es el conocimiento obtenido en el proceso... de volvernos más capaces de reciprocidad a través de la construcción y del reconocimiento de la intersubjetividad". Por eso, el énfasis en la solidaridad convierte la comunidad en el campo privilegiado del conocimiento emancipador". ${ }^{10}$ Se trata de una forma nueva de comunidad, que emerge después de que la modernidad ha socavado las formas de arraigo territorial: "La neo-comunidad transforma lo local en una forma de percepción de lo global, y lo inmediato en una forma de percepción del futuro". Así pues, "desde la perspectiva de lo post-moderno de oposición" que propone Santos, "la opción epistemológica más adecuada a la fase de transición paradigmática... consiste en la revalorización y reinvención de una de las tradiciones marginadas de la modernidad occidental: el conocimiento-emancipación. No es fácil formular una opción como esta y, aún menos, seguirla... No podemos proseguir sino por la vía de la negación crítica" (SC, pp. 86-90).

\subsection{Una distinción cultural: entre naturaleza y cultura, y entre ciencias naturales y ciencias sociales}

Santos explica a continuación cuál es esa vía negativa, que ya ha estado siguiendo en las estrategias indicadas. El siguiente paso es la negación de la objetividad pura como forma de conocimiento: "Todo el conocimiento es autoconocimiento". $\mathrm{O}$, dicho de otra manera: "El objeto es la continuación del sujeto por otros medios. Por eso todo el conocimiento emancipador es autoconocimiento... Los presupuestos metafísicos, los sistemas de creencias, los juicios de valor, no están antes ni después de la explicación científica de la naturaleza o de la sociedad. Son parte integrante de esa misma explicación".

Viene después otro paso: la negación de la separación tajante entre naturaleza y cultura: "Toda la naturaleza es cultura". Dice Santos: "La cultura pasó de ser artefacto entrometido en un mundo de naturaleza a ser expresión de la conversión de la naturaleza en artefacto total. Más aún..., esta transformación sólo fue factible porque la naturaleza, en cuanto objeto de conocimiento, fue siempre una entidad cultural". La distinción entre naturaleza y cultura, y entre ciencias naturales y ciencias sociales es, pues, cultural, y "nos permite visualizar los procesos sociales y políticos que presidieron su formación y desarrollo". Por 
ejemplo, nos permite mostrar que "la ciencia moderna, además de moderna, es occidental, capitalista y sexista. Esta triple adjetivación" quiere "señalar que la 'matriz de privilegio' ... de la producción científica moderna combina el racismo con el clasismo y el sexismo".

Santos estudia a continuación cada uno de estos sustantivos. Toma como ejemplo el darwinismo y recuerda que "el propio Darwin reconoce que la teoría de la selección natural se le ocurrió al leer el Ensayo sobre los principios de la población de Malthus... La lucha por la existencia y lo que ella implicaba - la escasez y la concurrencia-, conducían a lo que más tarde Spencer "llamó la 'supervivencia de los más aptos'... Marx, en carta a Engels, tres años después de la publicación de El Origen de las especies, comentaba cómo Darwin había reconocido entre los animales y las plantas a su sociedad inglesa con su división del trabajo, concurrencia, apertura de nuevos mercados, invenciones y lucha maltusiana por la existencia". Y concluye Santos: "Si es verdad que Darwin absorbió en su teoría la ideología del liberalismo, no es menos cierto que esa teoría fue utilizada por teóricos sociales para probar la naturalidad $y$, por tanto, la inevitabilidad de la referida ideología". El otro ejemplo que Santos utiliza es el de la primatología que, en Occidente "constituye... un discurso occidental sobre el orden social", y es diferente de la primatología japonesa, por ejemplo, que "se basa en la idea de una continuidad y de una unidad esencial entre seres humanos y animales". Respecto al sexismo, escribe Santos: "El etnocentrismo occidental, reconocible en la teoría de la evolución de Darwin, se desdobla en androcentrismo". Y añade que "los estudios feministas... han sacado a luz que, en las concepciones dominantes de las varias ciencias, la naturaleza es un mundo de hombres, organizado según principios socialmente construidos, occidentales y masculinos, como... la guerra, el... individualismo,... la concurrencia,... la agresividad, y... la discontinuidad con el medio ambiente". Incluso "en el caso de la filosofía" el feminismo actual "lo descubre" - al androcentrismo, por supuesto- "en la preponderancia del 'método antagonístico' en cuanto paradigma de razonamiento filosófico".

El último paso en esta vía de la crítica negativa lo da Santos al intuir que "todas las ciencias son ciencias sociales". Escribe así: "La transformación de la naturaleza en un artefacto global, gracias a la imprudente producción-destrucción tecnológica, y la crítica epistemológica del etnocentrismo y androcentrismo de la ciencia moderna, convergen en la conclusión de que la naturaleza es la segunda naturaleza de la sociedad... Toda naturaleza es humana. Si es así, todo el conocimiento científico-natural es 
científico-social". Pero acota: "Este paso epistemológico es uno de los más decisivos en la transición paradigmática... Es, también, un paso particularmente difícil de dar". Se trata de acceder al modo social como las recientes ciencias de la naturaleza están explicando los procesos que estudian, introduciendo "en la materia los conceptos de historicidad y de progreso, de libertad, de autodeterminación y hasta de conciencia...". También algunos conceptos de las teorías científiconaturales más recientes, como "estructuras disipativas", "situación de bifurcación" —ambos originales de Prigogine-, "sinergia" — Haken-, etc., encuentran campo de aplicación en las ciencias sociales: "Es como si la máxima de Durkheim se hubiera invertido, y en vez de ser los fenómenos sociales los que tienen que ser estudiados como si fueran... naturales, sean" estos "los que deben ser estudiados como si fuesen fenómenos sociales".

Santos nos recuerda que en la tradición sociológica hay una corriente positivista, pero que la otra corriente "de vocación antipositivista, inmersa en una tradición filosófica compleja, fenomenológica, interaccionista, mito-simbólica, hermenéutica, existencialista y pragmática..., reivindica la especificidad del estudio de la sociedad", claro que cediendo al antiguo paradigma en el hecho de que mantiene una "concepción mecanicista de la na- turaleza". Pues bien, "la pujanza de esta segunda vertiente... indica ser ella el modelo de las ciencias sociales que, en una época de revolución científica, contiene la marca postmoderna del paradigma emergente... Es un modelo en que lo que lo prende al pasado es menos fuerte que aquello que lo liga al futuro".

En última instancia, "a medida que las ciencias naturales se aproximan a las ciencias sociales, éstas se aproximan a las humanidades... Pero esta revalorización" de las humanidades, "no ocurrirá sin que las humanidades sean, también, profundamente transformadas. Lo que hay en ellas de futuro es el haberse resistido a la separación entre sujeto y objeto y entre naturaleza y cultura, y haber preferido la comprensión a la manipulación del mundo". Termina Santos: "La ciencia postmoderna es una ciencia conscientemente analógica, que conoce lo que conoce peor a través de lo que conoce mejor". Utiliza "la analogía textual..., la analogía lúdica..., la... dramática" e "incluso la biográfica... El mundo que hoy es natural o social y mañana será de las dos maneras" será estudiado, según "el paradigma emergente", como "un texto, como un juego, como un escenario, o, incluso, como una autobiografía", que "pueden... transformarse en proyectos locales emancipadores de un conocimiento post-moderno indivisible" (SC, pp. 90-105). 


\subsection{El conocimiento emancipador post-moderno es retórico: la novísima retórica}

¿Con qué tipo de argumentación va a trabajar el conocimiento-emancipación? Contrapuesto a la forma apodíctica de la argumentación científica demostrativa, "el conocimiento emancipador post-moderno es retórico", para Santos. "La verdad es retórica, una pausa mítica en una batalla argumentativa continua e interminable... entre varios discursos de verdad; es el resultado, siempre provisional, de una negociación de sentido". Y continúa: "De hecho, la pregunta sobre la existencia y la naturaleza de una transición paradigmática es, en sí, una pregunta retórica... En un periodo de transición paradigmática,... lo que está en juego no es una decisión sobre la validez de los nuevos descubrimientos, sino la existencia o no de una nueva percepción de la realidad". Santos afirma que la ciencia moderna es retórica, en un sentido fuerte, y descansa sobre la "fiducia", la credibilidad de la comunidad científica. Pero cree que...

El análisis retórico de la ciencia moderna nos dice muy poco acerca del conocimiento post-moderno de oposición que estoy proponiendo: un conocimiento-emancipación construido a partir de las tradiciones epistemológicas marginalizadas de la modernidad occidental. La única cosa que nos dice es que este conocimiento asume completamente su carácter retórico: un conocimiento prudente para una vida decente... La crítica radical a la nueva retórica debe, por tanto, conducir a una novísima retórica.

En opinión de Santos, "la novísima retórica debe privilegiar el convencimiento —adhesión basada en la valoración de las razones para actuar - en detrimento de la persuasión — adhesión basada en la motivación para actuar-", y así "acentuar las buenas razones en detrimento de la producción de resultados". Santos piensa que "una retórica que privilegie la obtención de convencimiento tenderá a contribuir... a un mayor equilibrio entre razones y resultados, entre contemplación y acción, y..., a una mayor indeterminación de la acción, dos presupuestos de un conocimiento prudente para una vida decente en un periodo de transición paradigmática".

Además "la novísima retórica deberá intensificar la dimensión dialógica". Pero, ¿dónde? En la "neocomunidad ya referida más arriba", una "comunidad interpretativa" o "auditorio" que "está en permanente formación", porque "es un proceso social". La novísima retórica "parte de dos presupuestos:... que en el sistema mundial capitalista la 
realidad social no puede reducirse a la argumentación y al discurso", y "que la retórica no es liberadora por naturaleza". ¿Qué significa el primer presupuesto? Que "más allá de la argumentación y del discurso, hay también trabajo y producción, silencio y silenciamiento, violencia y destrucción". Es decir, una "dialéctica entre momentos argumentativos y no argumentativos", que conduce a una "interpenetración de conflictos y consensos mundiales con conflictos y consensos locales". En última instancia, "el potencial emancipador de la retórica se basa en... procesos analíticos que permitan descubrir la razón de por qué, en determinadas circunstancias, ciertos motivos parecen ser mejores y ciertos argumentos más poderosos. En resumen, la novísima retórica comporta" constitutivamente "una sociología de la retórica". Retórica, sociología de la retórica y "hermenéutica" constituyen el conocimiento-emancipación (SC, pp. 105-119).

\subsection{Una segunda ruptura epistemológica: un sentido común nuevo y emancipador}

Santos propone una segunda ruptura epistemológica, más allá de la primera, que distingue entre conocimiento científico, que se atribuye a sí mismo "el prejuicio de pretender no tener prejuicios", y sentido común como "mera opinión o prejuicio". ¿En qué consiste esa segunda ruptura? "El conocimientoemancipación tiene que romper con el sentido común conservador, mistificado y mistificador, no para crear una forma autónoma y aislada de conocimiento superior, sino para transformarse a sí mismo en un sentido común nuevo y emancipador". ¿De qué sentido común hablaríamos? Nos acercamos a su sentido cuando captamos que...

El conocimiento-emancipación sólo se constituye en cuanto tal en la medida en que se convierte en sentido común. Sólo así será un conocimiento claro que cumple el aforismo de Wittgenstein: 'todo lo que puede decirse, puede decirse con claridad'... El conocimiento-emancipación, al tornarse sentido común, no desprecia el conocimiento que produce tecnología, sino entiende que... el desarrollo tecnológico debe traducirse en sabiduría de vida. Es esta la que señala los marcos de la prudencia a nuestra aventura científica.

Esto sucede en el proceso histórico de formación continua de una neo-comunidad, donde se pasa del "colonialismo como forma específica de ignorancia" a la solidaridad:
"La solidaridad en cuanto forma de conocimiento es la condición necesaria de la solidaridad en cuanto práctica política". 
Santos propone que "el sentido común emancipador es un sentido común discriminador (o desigualmente común...) construido para ser apropiado privilegiadamente por los grupos sociales oprimidos, marginados o excluidos". De todas maneras, los lugares comunes -topoi-, tan importantes en la retórica, han de ser vistos, a la luz de la sociología de la retórica, como reflejos y constitutivos de "las relaciones sociales dominantes en una comunidad o auditorio dados". Sin embargo, "como las comunidades son relaciones sociales", Santos defiende "la tesis de que las formaciones sociales capitalistas están constituidas por seis conjuntos de relaciones sociales... o espacios-tiempos: el espacio doméstico, el espacio de la producción, el espacio del mercado, el espacio de la comunidad, el espacio de la ciudadanía y el espacio mundial". Y continúa afirmando que...

No puede haber emancipación sin una tópica - es decir, un conjunto dominante de lugares comunes- de emancipación. Y eso presupone la sustitución, en el espacio doméstico, de una tópica patriarcal por una tópica de liberación de la mujer; en el espacio de la producción, la sustitución de una tópica capitalista por una tópica eco-socialista; en el espacio del mercado, la sustitución de una tópica del consumismo fetichista por una tópica de necesidades fundamentales y satisfacciones genuinas; en el espacio de la comunidad, la sustitución de una tópica chauvinista por una tópica cosmopolita; en el espacio de la ciudadanía, la sustitución de una tópica democrática débil por una tópica democrática fuerte; en el espacio mundial, la sustitución de una tópica del Norte por una tópica del Sur.

Recordando, finalmente, los monopolios de interpretación -la familia, la religión, el Estado y el partido-, Santos concluye: "La única vanguardia legítima es el sentido común de vanguardia". Porque "es inherente al discurso argumentativo... que esa invención nunca será completa y nunca alcanzará un punto de irreversibilidad" (SC, pp. 120-125).

\subsection{La repolitización global de la vida colectiva}

Sobre la base de esta construcción del nuevo paradigma en transición desde la supremacía del conocimiento-regulación en las ciencias sociales modernas hasta su compensación con el conocimiento-emancipación, Santos extrae conclusiones explícitamente 
políticas. Primero, "para un nuevo sentido común político: un sentido común participativo". Escribe: "tal y como la dimensión de la solidaridad confiere al nuevo sentido común su marca ética, la dimensión de la participación le confiere la marca política". Y lo explica en uno de los pasajes más importantes de su obra: "Uno de los procesos que condujeron a que el equilibrio entre regulación y emancipación quebrase a favor de la regulación consistió en la reducción de la política a una práctica sectorial y especializada y en la rígida regulación de la participación de los ciudadanos en esa práctica".

Al contrario de una celebrativa post-modernidad "miope" que quiso despolitizar "pseudo-radicalmente" la sociedad, "el conocimientoemancipación tiende... a una repolitización global de la vida colectiva". En primer lugar, 'la hiperpolitización' moderna "del Estado... es el otro lado de la despolitización de la sociedad civil". Así fue limitado el "ideal democrático de la política moderna". En segundo lugar, "cuanto más vasto sea el dominio de la política, mayor será el de la libertad", como ya lo escribió Arendt al criticar el concepto liberal de libertad. ${ }^{11}$ Piensa Santos que tenía razón Foucault al afirmar que "todas las relaciones de poder son políticas", aunque, al contrario de él, no renuncia "a estructurar y a jerarquizar las formas de poder $y$ de relaciones de poder", porque "si el poder está" de igual modo "en todos lados, no está en ninguno". Santos cree que existen seis formas de poder correspondientes a los seis espacios de la tópica de emancipación. Y concluye: "A la novísima retórica emancipadora le compete cuestionar" la premisa moderna de que "la política sólo se refiere al espacio de la ciudadanía... De todas las tareas que caben a la novísima retórica, esta es, a mi modo de ver, la más problemática" (SC, pp. 127128).

\subsection{Seis formas de poder correspondientes a seis formas de emancipación}

Santos responde así: "El patriarcado es la forma de poder privilegiada en el espacio doméstico". Y añade: "Las relaciones sociales... alrededor del espacio doméstico (trabajo doméstico, reproducción, cuidados mutuos, gestión de los bienes..., educación de los hijos, ocio, placer, etc.) son organizadas generalmente por el patriarcado en cuanto sistema de control de los hombres sobre la reproducción social de las mujeres".

En segundo lugar, "la explotación, tal y como Marx la definió, es la forma de poder privilegiada en el espacio de la producción". Pero, para tener en cuenta no solo "la explotación del trabajo", sino también "la degradación de la naturaleza", hay que añadir "la 'naturaleza capitalista', o sea la naturaleza como 
construcción histórica y social 'producida', conjuntamente, por la ciencia moderna y por el capitalismo".

En tercer lugar, "el fetichismo de las mercancías es la forma de poder del espacio del mercado". Santos dice que "el sentido con que" utiliza "aquí la expresión es semejante al de Marx", es decir, el hecho de que las mercancías, producto de sus productores, niegan a estos mismos, convirtiéndolos en criaturas suyas, o seduciéndolos y despojándolos de su libertad frente a esos productos.
En cuarto lugar, "la diferenciación desigual es la forma de poder privilegiada en el espacio de la comunidad y, probablemente, la más compleja y ambigua de todas... Esta forma de poder se centra en torno al privilegio de definir al otro". El punto está en que "para los que son supuestamente incapaces de definirse y representarse a sí mismos, la cuestión de la identidad es... una cuestión de resistencia cultural, de hacer que el subalterno hable". Es importante y compleja la relación de esta forma de poder, por ejemplo, con la explotación:

La reetnización de la fuerza de trabajo como medio de desvalorización de la misma hacia escalones inferiores a los niveles capitalistas 'normales': la sobre-explotación de los trabajadores emigrantes clandestinos; la distribución social de grupos minoritarios por mercados de trabajo especialmente degradados (trabajo estacional, trabajo precario, trabajo remunerado por abajo del salario mínimo); criterios y decisiones, étnicamente sesgados, en relación a los refugiados; mercantilización de los recursos naturales de los pueblos indígenas promovida por las empresas multinacionales que explotan la biodiversidad, o la minería, etc.

Lo que sucede es que "la reestructuración de la acumulación del capital a escala mundial está obligándonos a refinar nuestros instrumentos analíticos y a reinventar la historia moderna", para salir de "una acumulación de negligencia teórica sobre una forma de poder... considerada anacrónica, residual, precapitalista", y llegar a "percibir las nuevas (y viejas) constelaciones de poder", indicadas arriba.
En quinto lugar, "la dominación es la forma de poder privilegiada en el espacio de la ciudadanía. Es la única forma de poder que tanto la teoría política liberal como la marxista consideraban poder político..., generado en el sistema político y centrado en el Estado". Santos distingue entre "dominación como poder cósmico y el resto de formas de poder como poder caósmico". Aquel sería "el poder centralizado, 
ejercido a partir de un centro de alto voltaje (el Estado) y dentro de límites formalmente establecidos" por "cadenas institucionalizadas de intermediación burocrática". ${ }^{12}$ "EI poder caósmico es el poder descentralizado e informal. Todas las constelaciones de poder combinan un componente cósmico con una pluralidad de componentes caósmi$\cos ^{\prime \prime}$. El que se vivencie una u otra de estas formas de poder y a ella se reduzcan las constelaciones de poder, "afecta negativamente a la eficacia de las luchas de resistencia contra el poder, dado que éste es siempre simultáneamente cósmico y caósmico".

Finalmente, "la forma de poder del espacio mundial" es el "intercambio desigual", alrededor del cual "existe una larga tradición analítica, marcada particularmente por las teorías del imperialismo, de la dependencia y del sistema mundial". La teoría del sistema mundial compuesto de centro, semiperiferia y periferia, ayuda a explicar la trasferencia de capital y de materias primas (coltan, diamantes, oro, molibdeno, uranio, crudo, etc.) hacia el centro, y el pago de salarios inferiores, a igual uso de tecnología, en la periferia y semiperiferia. Las constelaciones del intercambio desigual con la explotación, el fetichismo de las mercancías, la dominación y el patriarcado, ayudan a vislumbrar la complejidad de las relaciones transnacionales o globales actuales (SC, pp. 324-330).

\subsection{Reinventar el pasado para superar la inutilización del futuro}

En un libro posterior, Santos retoma la idea de la caída de los paradigmas modernos de revolución y reforma, y al interior de este último, la idea del ocaso del EstadoProvidencia o Estado de Bienestar. Recuerda que la modernidad ha puesto sus esperanzas en el futuro, y piensa que con "la inutilización del futuro", "no podemos pensar en la transformación social si no reinventamos el pasado". No se trata, pues, de vivir solo de una memoria, sino de "volver a pensar en la emancipación social a partir del pasado y, de algún modo, de cara al futuro". Santos recoge el famoso pasaje de Walter Benjamin sobre el cuadro de Klee, Angelus Novus, una pintura que adquirió fama también en Guatemala por ocupar, en forma recreada, la portada de la obra de rescate de la memoria de las víctimas de la guerra y de la represión ¡Guatemala, nunca más!, tras cuya publicación, en abril de 1998, se produjo el asesinato del obispo Juan Gerardi, su impulsor. Santos comenta así el pasaje de Benjamin:

El ángel de la historia contempla, impotente, la acumulación de ruinas y de sufrimiento a sus pies. Le gustaría... echar raíces en la catástrofe para, a partir de ella, despertar 
a los muertos y reunir a los vencidos, pero la fuerza de la voluntad cede frente a la fuerza que lo obliga a escoger el futuro, al cual le da la espalda. Su exceso de lucidez se combina con la falta de eficacia... Así, el pasado es un relato y nunca un recurso, una fuerza capaz de irrumpir en un momento de peligro para auxiliar a los vencidos. Lo mismo dice Benjamin en otra tesis sobre la filosofía de la historia: "Articular el pasado históricamente no significa reconocerlo 'como fue en realidad'. Significa apoderarnos de una memoria tal como ella relampaguea en un momento de peligro..." La capacidad de redención del pasado radica en la posibilidad de surgir inesperadamente en un momento de peligro, como fuente de inconformismo. ${ }^{13}$

\subsection{Que el inconformismo de los muertos provoque el de los vivos}

Para que "el inconformismo de los muertos" provoque el de los vivos. Benjamin escribía este texto en un tiempo de muertos, el tiempo del nazismo de Hitler. Santos piensa que "al igual que Benjamin, atravesamos un momento de peligro...", pero que, gracias a "la crisis por la que está atravesando la idea de progreso", hay una oportunidad histórica y es tan "importante... colocar al ángel de la historia en otra posición, reinventar el pasado a modo de restituirle la capacidad de explosión y redención". Es lo que hace el cuarto de los ángeles de la portada de ¡Guatemala, nunca más!, después de que los tres primeros se han tapado los ojos, los oídos y la boca: abre la boca para gritar y vocear el pasado. Pero, según Santos, a partir de ahí se trata de reinventarlo. Los partidos políticos de izquierda deberían hoy en Centroamérica tratar de despertar el inconformismo de los vivos con la sociedad actual y consigo mismos evocando el inconformismo de los muertos en las guerras revolucionarias de los años setenta y ochenta.

\subsection{La complementación entre "raíces" y "opciones"}

Estudia Santos a continuación la complementación entre "raíces" y "opciones". "El pensamiento de las raíces es el pensamiento de todo lo profundo, permanente, singular, todo aquello que da seguridad $y$ consistencia". Por el contrario, "el pensamiento de las opciones es el pensamiento de todo aquello que es variable, efímero, sustituible, posible e indeterminado a partir de las raíces". Y añade: en el pensamiento moderno "no existe la opción si no se piensa en términos de raíces y opciones". ¿Qué se expresa en realidad? Una ecuación sostenida por dos estratagemas; la primera el "equilibrio entre el pasado y el fu- 
turo", de manera que en la modernidad "el pensamiento de las raíces se presenta como un pensamiento del pasado en contraposición con el pensamiento de las opciones, el pensamiento del futuro"; pero se trata de una estratagema porque ambos son pensamientos de futuro, "el pasado, en esta ecuación, es tan sólo una manera específica de construir el futuro". La segunda estratagema es —dice Santos- la del "equilibrio entre raíces y opciones". La verdad es que no es así. Santos piensa que siempre hay un predominio de opciones, aunque en una época histórica se dé más importancia a las raíces y en otra a las opciones.

\subsection{En la sociedad medieval y su contraposición en la sociedad moderna}

¿Qué importancia tiene esto? Lo muestra Santos con algunos ejemplos. "La sociedad medieval es vista como una en la cual las raíces predominan totalmente, sean éstas la religión, la teología o la tradición". En cambio, "la sociedad moderna se ve como una sociedad dinámica, que evoluciona siguiendo una lógica de opciones". Con el protestantismo, por ejemplo, "la religión, al volverse optativa", "a partir de la misma raíz — la Biblia de la cristiandad occidental-_", "pierde intensidad e incluso estatus, en cuanto raíz". La ley de la naturaleza es la que se vuelve raíz predominante. Ahora bien, "en el mismo proceso histórico en que la religión transita del estatus de raíz al de opción, la ciencia transita... del estatus de opción al de raíz".

En la Ilustración, la razón se vuelve una de las raíces fundamentales de todas las opciones, individuales y colectivas. Así, "la razón se distingue... de las raíces de la sociedad del Ancien régime (la religión, la tradición)", y "abre el campo a enormes opciones". Sigue Santos: "La otra gran raíz de la Ilustración" es "el contrato social y la voluntad general que lo sustenta". Se trata de "la metáfora que origina una opción radical —la de dejar el estado de naturaleza para formar la sociedad civil- que se transforma en una raíz a partir de la cual casi todo es posible, todo excepto volver al estado de naturaleza. La contractualización de las raíces es irreversible".

\subsection{En el viaje}

Santos piensa que la ecuación entre raíz y opciones tiene un ejemplo importante en el viaje, con su "carga simbólica doble": "símbolo del progreso y enriquecimiento material o cultural" y "del peligro, de la inseguridad y de la pérdida". En el primer polo están los hombres blancos, ricos, cultos. Por el otro se encuentran las mujeres, los negros, los pobres. "El... viaje es lo que mejor muestra la discriminación y desigualdad que la ecuación moderna raíces/opciones oculta y procura 
justificar". El viaje forzoso de los esclavos para ser vendidos lejos de su tierra es el mejor ejemplo. El viaje de Ulises a la guerra y el retorno aventurero de ella, mientras Penélope esperaba tejiendo, es "la versión arquetípica" del falocentrismo del viaje: "Las raíces que otorgan opciones a los hombres, a los blancos y a los capitalistas, son las mismas que las niegan a las mujeres, a los negros y a los trabajadores". Y se puede añadir, entre nosotros, a los pueblos originarios. El viaje -la opción-, y la casa —la raíz- de donde se parte y a donde se vuelve no son iguales para todos.

\subsection{En "la idéologie savante de las ciencias sociales"}

Pero al final del siglo XIX, "el juego de espejos" entre raíces y opciones se vuelve "la idéologie savante de las ciencias sociales". En la teoría de Marx, la raíz es la estructura y las opciones la superestructura. En Durkheim, "la conciencia colectiva es la raíz, siempre amenazada" por la división del trabajo, la anomia, etc. Para Freud y Jung, la raíz es el inconsciente y las opciones están en "el ego o su limitación neurótica”. Según Santos, "el materialismo histórico y la psicología profunda se proponen ir a las raíces de la sociedad moderna - del capitalismo y de la cultura occidental, respectivamente- para abrir opciones nuevas y más amplias". Santos desemboca también en la otra margen del liberalismo, del cual el marxismo es una ${ }^{14}$ : "La traducción política liberal de esta nueva ecuación entre raíces y opciones es el Estado-nación y el derecho positivo, convertidos en las raíces que crean el inmenso campo de las opciones en el mercado y en la sociedad civil". Lo cual quiere decir que "el Estado liberal se constituyó como raíz gracias a la imaginación de la nacionalidad homogénea y de la cultura nacional" (SM 117-123).

\subsection{Momento peligroso actual de la ecuación moderna entre raíces y opciones: turbulencia de las escalas}

Santos piensa que "la ecuación moderna entre raíces y opciones, con la que aprendemos a pensar la transformación social" está atravesando un momento de "profunda desestabilización", algo parecido al "momento peligroso" de Benjamin. Piensa que esta desestabilización parece "irreversible", y que se presenta "bajo tres formas principales: turbulencia de las escalas, explosión de raíces y opciones, y trivialización de la ecuación entre raíces y opciones". En su teoría, las raíces ocurren a gran escala y las opciones a pequeña escala. Pero hoy vivimos una "confusión caótica de escalas entre fenómenos".

La violencia urbana es paradigmática en este sentido. Cuando un niño de la calle busca abrigo para pasar la noche y 
por esa misma razón es asesinado por un policía, o cuando una persona es abordada por un mendigo en la calle y al negarse a dar limosna es asesinada por éste, lo que ocurre es una explosión imprevisible en la escala del conflicto... Este cambio abrupto e imprevisible en la escala de los fenómenos ocurre en la actualidad en los más diversos dominios de la práctica social, por lo que me atrevo a considerarlo como una de las características fundamentales de nuestro tiempo.

Se aplicaría aquí la noción de "periodo de bifurcación", de Prigogine, cuando en sistemas inestables "un cambio mínimo puede producir transformaciones cualitativas de modo imprevisible y caótico". En esta turbulencia reside "la enorme vulnerabilidad a que están sujetas las formas de subjetividad y de sociabilidad: del trabajo a la vida sexual, de la ciudadanía al ecosistema". En esta misma situación de inestabilidad del sistema pueden adquirir sentido el desmoronamiento de la Unión Soviética, la inestabilidad política de los Balcanes, del Medio Oriente o de África. Ya habían ocurrido estos cambios con la erupción de descolonización en África y Asia después de la Segunda Guerra Mundial. "Lo nuevo es precisamente el hecho" de que estos cambios "se llevarán a cabo sobre las ruinas de Estados que habían reclamado para sí la titularidad de las raíces de identidad". En el campo de la economía, "el ajuste estructural para los países del Sur, lejos de ser una opción, es una raíz transnacional que envuelve y asfixia las raíces nacionales". Lo mismo pasa con el contrato social, un contrato-raíz: "Doscientos años después, el desempleo estructural, el recrudecimiento de las ideologías reaccionarias, el aumento exagerado de las desigualdades económicas..., el hambre, la miseria" en el Sur y en "el Tercer Mundo interno" del Norte, "nos hace creer que estamos ante la opción de excluir del contrato social a un fragmento significativo de la población de nuestros países, y obligarlo a que vuelva a su estado natural".

\subsection{Explosión simultánea de las raíces y las opciones en la globalización}

Por lo que toca a "la explosión simultánea de las raíces y las opciones", el campo de la globalización es el que ofrece mejor oportunidad para captarla. La "'globalización', una articulación de la sociedad de consumo con la sociedad de la información", una nueva raíz, "ha dado origen a la multiplicidad infinita, en apariencia, de opciones. El campo de posibilidades se ha expandido enormemente, legitimado por las propias fuerzas que hacen posible tal expansión..., la tecno- 
logía, la economía de mercado, la cultura global de la publicidad y el consumismo o la democracia". Pero, al igual que Castells, Santos observa que "en aparente contradicción... vivimos una época de localismos y territorialidades, de identidades y singularidades, de genealogías y memorias; en suma... de multiplicación... de las raíces". Pero la explosión de que habla Santos, "surge también por la búsqueda de raíces más profundas y fuertes, que sustenten opciones dramáticas y radicales". "Los dos ejemplos más elocuentes... son los fundamentalismos y la investigación sobre el ADN". Piensa Santos que "el fundamentalismo liberal" es el más intenso de todos los fundamentalismos. "El capitalismo se volvió marxista. La economía de mercado, el último seudónimo del capitalismo, se transformó... en el nuevo contrato social... que empuja a la mayoría de los países... a elegir entre el caos de la exclusión y el caos de la inclusión". "El boom" de la investigación sobre el ADN "puede interpretarse como otro medio de convertir el cuerpo en la raíz última. Comenzamos el siglo XX con la revolución socialista y la revolución introspectiva, y lo terminamos con la revolución corporal. El papel central que... asumieron la clase y la psique, en la actualidad lo ha asumido el cuerpo, convertido, al igual que la razón ilustrada, en la raíz de todas las opciones".

\subsection{Trivialización de la ecuación entre raíces y opciones}

Nos queda por ver lo que Santos llama "la trivialización de la ecuación entre raíces y opciones". La ecuación raíces/opciones "sólo parece tener sentido en una cultura conceptual, logocéntrica, que discurre sobre matrices sociales y territoriales (espacio y tiempo) y las somete a criterios de autenticidad". En cambio, "a medida que transitamos hacia una cultura centrada en imágenes, el espacio y el tiempo van siendo sustituidos por los instantes de la velocidad, las matrices sociales... por mediatrices ${ }^{15} y$, en el mismo nivel, el discurso de la autenticidad se transforma en una jerga indescifrable...". En este ciberespacio, "la ecuación entre raíces y opciones ora hace que todo tenga sentido, ora hace que nada tenga sentido... Estas oscilaciones de sentido son, tal vez, la causa última de la trivialización entre raíces y opciones, la tercera manifestación de la desestabilización de esta ecuación en nuestro tiempo... La trivialización de la distinción entre raíces y opciones implica la trivialización de unas y otras". Piensa Santos, por el contrario, que "el pathos de la distinción entre raíces y opciones es inherente al modo moderno de pensar la transformación social", mientras que, "en ausencia de ese pathos, el presente tiende a eternizarse y a devorar de igual forma 
el pasado y el futuro... El presente eterno conforma la equivalencia entre las dos ilusiones", una de estancamiento en el pasado y otra de vértigo frente al futuro. "Y a la vez las neutraliza. Con ello, nuestra condición asume una dimensión kafkiana: lo que existe no tiene explicación, ni por el pasado ni por el futuro. Existe a penas en un mar de indefinición y de contingencia".

Santos compara la presencia en la religión y la filosofía con la presencia digital. Aquella "es la fulguración única e irrepetible de una relación sustantiva, producto de una interrogante permanente, sea éste el acto místico, la superación dialéctica, la realización del Geist [espíritu], del Selbstsein [ensimismamiento], el acto existencial o el comunismo". Esta "es, por el contrario, la fulguración de una relación de estilo, repetible una y otra vez; una respuesta permanente a todos los posibles interrogantes. Se opone a la historia sin tener la conciencia de que es histórica. Por eso imagina el fin de la historia sin tener que imaginarse su propio fin" (SM 123-128). Personalmente me la imagino como la fulguración de las Cumbres políticas, de las reuniones en Davos, de las pasarelas de la moda, de los Bestsellers, de los concursos de Miss Universo, de la Champions League, o de los grandes espectáculos litúrgicos globales.

\subsection{Recuperar la capacidad para el espanto como impulso para la transformación social}

De algún modo, son y representan "la época de repetición". Cuando la transformación social no solo resulta "impensable", como aparentemente después del "final de la historia", y como sucedía pienso- antes de la gran crisis de la globalización financiera y económica, sino que además aparece como "innecesaria", debemos recuperar de nuevo la capacidad para el "espanto", al modo de Walter Benjamin en 1940, y así "verificar que la teoría de la historia de la modernidad es insostenible", que es necesario profundizar "las energías de emancipación", y, en este momento de peligro, "contar con una nueva capacidad de espanto y de indignación que sustente una nueva teoría y una nueva práctica de inconformismo desestabilizadora, es decir, rebelde".

Santos coincide aquí con una característica fundamental, tanto de la teología de la liberación como de la teología política: "hablar desde Ayacucho", diría Gustavo Gutiérrez, es decir desde el horror causado por Sendero Luminoso y el ejército peruano, retener - en estos tiempos de Alzheimer social_ - la memoria del holocausto judío y a la vez la de los campos arrasados de refugiados palestinos (Sabra y Shatila) —diría Metz-, la memoria de la gente masacrada por la bomba atómica en 
Hiroshima y Nagasaki, la memoria de los once millones de congoleños aniquilados por Leopoldo II de Bélgica, de los bombardeos brutales de Hamburgo y Dresde, del genocidio en Ruanda, de los 12 millones de muertos en la guerra del coltan alrededor de Los Grandes Lagos, la memoria de la gente masacrada en el Sumpul, en el Mozote y en la UCA (lugares de peregrinación en El Salvador), la memoria también de la gente masacrada en Cuarto Pueblo, en Xalbal y en San Francisco Nentón (Guatemala), la memoria de las bombas de quinientos kilos lanzadas sobre Managua por la Guardia de Somoza, recuperar el pasado sin permitir que nos acostumbremos a su simple y sencillo haber acontecido.

Esta recuperación no puede quedarse únicamente en ser "guardianes del espanto pasado". Tiene que convertirse en lucha para subvertir hoy la violencia de los narcotraficantes y de los traficantes de armas, de las maras y de los guardianes del "santo dinero" tras los muros de Wall Street y de otros grandes "templos" financieros en el mundo, o de la sagrada explotación de los emigrantes tras los muros del Río Grande, y de la quema de excedentes de granos básicos o de frutas y verduras, mientras bolsones enormes de África y de otros lugares padecen el hambre de hoy y de mañana. $Y$ también del bandolerismo de la política de "grupos de choque" contra los que reclaman pensamiento plural y libertad para elegir en las urnas.

\subsection{El fatalismo es, en la concepción modernista, el otro lado de la confianza en el futuro. Ambos oscurecen el sufrimiento humano.}

"Para la teoría de la historia escribe Santos-, el pasado es una acumulación fatalista de catástrofes que el angelus novus observa de manera impotente y ausente". Y continúa con gran lucidez: "El fatalismo es, en la concepción modernista, el otro lado de la confianza en el futuro. El pasado queda así neutralizado en dos niveles: porque sucedió lo que tenía que suceder y porque lo que haya acontecido en un momento dado ya sucedió y puede llegar a superarse con posterioridad". Se trata de "una constelación de ilusiones retrospectivas y prospectivas". La política necesita, por tanto, "reinventar el pasado como negatividad, producto de la iniciativa humana $y$, basándose en él, construir interrogantes poderosos y adoptar posiciones apasionadas que tengan la capacidad de despertar sentidos fecundos". Escribe sobre "interrogantes poderosos" que "se traduzcan en imágenes desestabilizadoras". Así será "el inconformismo... la utopía de la voluntad". Pero, teniendo en cuenta que es "la iniciativa del ser humano y no cualquier idea abstracta" la que puede fundamentar "el principio esperanza". Por otro lado, "las imágenes desestabilizadoras serán eficaces solo si son ampliamente compartidas". Santos piensa que, 
"en el momento actual de peligro, el interrogante poderoso, para ser ampliamente distribuido, suele incidir más sobre lo que nos une que sobre lo que nos separa". Hay que superar la carencia de "teorías de unión", que contrapesen a la gran cantidad de "teorías de separación" que hemos forjado.

Santos nos ayuda cuando escribe que "los poderes hegemónicos que rigen la sociedad de consumo y la sociedad de la información han promovido... teorías e imágenes manipuladoras que ignoran las diversas circunstancias y aspiraciones de los pueblos, clases, géneros, regiones, etc., así como las relaciones de desigualdad, explotación y victimización..." Y cuestiona su credibilidad, que "consiste en apelar, aunque de manera manipuladora, a una comunidad imaginada de la humanidad en su conjunto". Señala el caso de CNN como típico en este asunto: "El sufrimiento existe en todas partes; los individuos son los que sufren, no las sociedades". El problema es que "las coaliciones y alianzas" de "las fuerzas contrahegemónicas... han sido poco eficaces". Es importante que se esfuercen "para que se vuelva visible lo que hay de común entre las diferentes formas de discriminación y de opresión: el sufrimiento humano". Santos apela al esfuerzo por crear y profundizar "la globalización contrahegemónica", que ha "designado como 'cosmopolitismo subalterno'...", algo que reconstituye "la idea del totus Orbis, formulada por Francisco de Vitoria, uno de los fundadores del derecho internacional".

\subsection{Crear un equilibrio dinámico entre las teorías de la separación y las teorías de la unión}

Lo que pretende Santos es "crear un equilibrio dinámico entre las teorías de la separación y las teorías de la unión", en cuatro niveles.

El primer nivel es epistemológico, o del conocimiento, como ya hemos visto. Subrayando que hay diferentes formas de conocer, es decir, de abrir los ojos sobre el mundo y comprenderlo, así como diferentes formas de ignorar. Recordemos la trayectoria del caos al orden —la epistemología que conduce desde el desorden salvaje de la naturaleza al orden civilizado de la sociedad (burguesa)- E. En esta trayectoria, "el sufrimiento humano puede justificarse... en nombre de la lucha del orden y del colonialismo contra el caos y la solidaridad" entre "trabajadores, mujeres, minorías étnicas y sexuales", todos ellos, y otros parecidos, grupos peligrosamente caóticos desde cierta perspectiva dominante, que comprenderá bien —pienso yo- quien haya leído a Saramago en Ensayo sobre la lucidez. Contraria puede llegar a ser la trayectoria epistemológica del colonialismo $^{16}$ a la solidaridad. La "imagen desestabilizadora" para 
lograr caminar esta trayectoria es "el sufrimiento humano". No podemos olvidar que ese mismo sufrimiento se convierte en las películas violentas de acción, alimento cotidiano de la televisión, en espectáculo atrayente y compulsivamente adictivo $\mathrm{o}$ ingenuamente distractivo.

El segundo nivel es "metodológico". La globalización consigue triunfar convirtiendo un desarrollo rival en definitivamente local y, por tanto, de menor importancia. Santos propone una "hermenéutica diatópica" para contrarrestar el truco globalizador. "El objetivo de la hermenéutica diatópica es el de llevar al máximo la conciencia de la incompletud recíproca de las culturas" que, por tanto, necesitan completarse mutuamente. Un ejemplo interesante, a un nivel banal, ya utilizado globalizadoramente, es - me parece- el de los alimentos culturalmente propios, que dan origen a restaurantes especializados en ellos. Santos propone otro ejemplo: la complementación entre "el tópos de los derechos humanos de la cultura occidental y el tópos del dharma en la cultura hindú" o con "el tópos de la umma en la cultura islámica". La imagen desestabilizadora sería el "epistemicidio", es decir "el asesinato del conocimiento" hegemónico, o del "pensamiento único", que diría Ramonet.

El nivel tercero es "político". Si bien los anteriores y el cuarto inciden también concatenadamente en las relaciones políticas, hay que suscitar, siguiendo a Richard Falk, una orientación de "gobierno humano (human governance)". Tanto las teorías de la unión, como el mercado o la democracia liberal, como las teorías contrahegemónicas de separación (por ejemplo, añado yo, obrerismo clasista, indigenismo antimestizo o antiblanco, feminismo estigmatizador de lo masculino, etc.), "han generado formas de barbarie, de exclusión y de destitución" - las primeras-, así como "prácticas neofundamentalistas o neotribales" —las segundas.

Es preciso — piensa Santossuscitar también aquí "una imagen desestabilizadora: la imagen del apartheid global, un mundo de guetos, sin entrada ni salida", que constituya "la energía de la orientación política del gobierno humano". Un gobierno que, en lugar de partir del presupuesto de la probabilidad de una "lucha de civilizaciones" a la Huntington, parta del fomento de la comunicación mutua intercultural y del "respeto y celebración de la diferencia, y una actitud de extremo escepticismo" frente a quienes enfatizan los exclusivismos, de manera que se pueda descubrir en las otras culturas y, por tanto, también en las otras personas diferentes la riqueza de la múltiple ciudadanía de este mundo. Lo contrario, "asociado a la guerra, las desigualdades abismales, y el colapso ecológico", nos acercaría a la perpetuación de la sospecha mutua generalizada que 
desemboca una y otra vez en el conflicto, de carácter bélico o de atentado terrorista.

Finalmente, el cuarto nivel es "jurídico". Lo que nos ayudaría en él —piensa Santos_ es "la doctrina 'patrimonio común de la humanidad". . A pesar de lo "vilipendiada" que ha sido "en la segunda mitad del siglo XX", es preciso seguir enfatizando que existen "campos sociales, físicos o simbólicos, que son res communis", es decir asunto de toda la humanidad: "El fondo marino, la Antártida, la Luna y otros cuerpos celestes, el ambiente global, la biodiversidad son algunos de los recursos que, si no son" confiados a ciertas entidades para ser administrados por ellas "a favor de las generaciones presentes y futuras", acabarán siendo apropiados, explotados y dilapidados conflictivamente por los más fuertes. Y "la vida en la Tierra se hará intolerable hasta dentro de los guetos de lujo que componen el apartheid global".
La imagen desestabilizadora será aquí "la parábola de la tragedia de los comunes", 17 que "será tanto más desestabilizadora cuanto más elevada sea la conciencia ecológica global". A fin de cuentas, los orígenes arquetípicos del patrimonio común en el origen del derecho internacional -la distinción de Vitoria entre "el derecho entre todas las naciones" y "la totalidad del mundo"; o la de Francisco Suárez entre "el derecho de gentes entre las naciones" y "el bien común de la humanidad" — eran esos "arquetipos" del patrimonio común. Piensa Santos que su pérdida hace de su recuperación algo "utópico o mesiánico", en el sentido de Benjamin. Para ello es necesario que "salga del discurso y las prácticas jurídicas del derecho internacional —donde siempre será vencido por los principios de propiedad y soberanía- y se transforme en un nuevo sentido común jurídico emancipador" (SM 129-138).

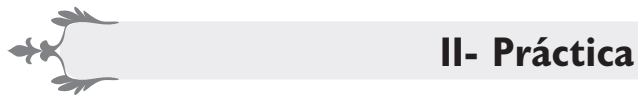

Expongo a continuación más concisamente los otros 11 retos de la izquierda en Centroamérica y, posiblemente, en otras partes. Su clave fundamental es que tampoco sin una práctica renovada que se enlace con la teoría, se puede llegar a una praxis (teoría y práctica) política adecuada.
2. Mantener un contacto privilegiado con la gente normal, es decir con la mayoría empobrecida y con las clases medias.

Este desafío se refiere al tipo de relaciones sociales que mantienen quienes participan en la izquierda. La mayoría, o por lo menos una buena parte, de quienes hoy se 
agrupan alrededor de un partido de izquierda, como dirigentes, militantes o simpatizantes, Ilegaron a adoptar esa opción política a través de la indignación. La indignación que les produjo vivir o conocer de cerca la dura condición humana en la que debían vivir los pobres en su país y en el mundo. La indignación ha sido siempre el motor humano fundamental que ha despertado la rebeldía ante la miseria o la pobreza de las mayorías, frente a la desigualdad que en su realidad más extrema se vuelve obscena, por ejemplo cuando se compara la forma como se vive lujosamente en barrios de El Salvador como Santa Elena, San Benito, etc, prácticamente amurallados en el lujo, y la forma como se vive en barrios como La Chacra. La forma como vive Ira Rennert, principal propietario de Renco Group Inc., en una mansión de 200 millones de dólares en The Hamptons (New York) ${ }^{18}$ y la forma como viven los habitantes de La Oroya (Perú), mineros de Renco o no, en una de las zonas más contaminadas del mundo. Haber estudiado la situación de la clase obrera en la Inglaterra del siglo XIX fue lo que llevó a Federico Engels a juntarse con Karl Marx en el Manifiesto Comunista.

Cuando los izquierdistas dejan de relacionarse con los pobres, cuando dejan de estar cerca de sus raíces, y más aún cuando trivializan la relación entre sus raíces y sus opciones políticas, cuando adoptan la explicación de que así, es decir, así de desigual es inevitablemente la sociedad, como un estadio donde hay localidades de palco, de preferencia, de sombra y de sol, y de general, $y$ donde mucha gente se queda fuera, y se quedan satisfechos con que las luchas revolucionarias han permitido el ascenso social de los líderes políticos de la izquier$\mathrm{da},{ }^{19}$ tocamos prácticamente el fin de la indignación y entramos en los dominios de la indignidad propios de la derecha rica. Dejamos de sentir en carne propia el dolor de la gente. O la ansiedad de las clases medias amenazadas de descenso social. Entonces nos habremos instalado. Habremos entendido ya que "el fin de ganar más dinero justifica los medios ${ }^{\prime 20}$ que conducen a que los pobres sigan siendo pobres.

\section{Vivir una vida austera que reivindique en la práctica lo que diferencia a la izquierda auténtica de la derecha: la tendencia a la mayor igualdad posible. Esto incluye una decisión ética de superar, al menos como personas y como grupo, el consumismo dominante (parte del "fetichismo de las mercancías").}

El lujo es una industria. Y como toda industria, se despliega en un comercio. En este caso, se trata de un comercio al que solo pueden acceder escasas minorías de la humanidad, pero que atrae - por 
la dinámica del "fetichismo de las mercancías" - también a las clases medias y hasta a las mayorías empobrecidas. El comercio de lujo tiene una manifestación muy especial en los vestidos y se despliega en las pasarelas de la moda, correspondientes a las cuatro estaciones del año (allí donde las hay), y en las tiendas exclusivas donde se exhiben los últimos modelos. Se manifiesta, igualmente, en los medios de movilidad, sobre todo en las marcas y los tamaños de los automóviles. E igualmente en los zapatos, en las maletas y bolsas de viaje, en las joyas, en los perfúmenes, en las marcas de licor, y sobre todo en el tipo de casa que se construye o donde se vive. El lujo es el modelo, más aún el paradigma del consumismo. Las clases medias no pueden darse los lujos que se permiten los que han alcanzado las cumbres de la vida social. Pero los grandes supermercados, los malls, y las marcas intermedias de automóviles, así como las urbanizaciones relativamente seguras, les ofrecen el equivalente del lujo de las clases altas. Incluso los pobres se citan muchas veces en los grandes supermercados para vivir de las compras con los ojos de tanto bien cuyo consumo les está vedado a sus modestos ingresos.

Ignacio Ellacuría habló de la civilización de la pobreza, contrapuesta a la civilización de la riqueza. Explícitamente escribió que "la civilización de la pobreza no pretende la pauperización uni- versal como ideal de vida". Lo que pretende es una economía fundada en la satisfacción de las necesidades principales de la humanidad. Una civilización cimentada en la solidaridad compartida. Una civilización que tenga "como principio dinamizador, frente a la acumulación del capital, la dignificación por el trabajo, un trabajo que no tenga por objetivo principal la producción de capital, sino el perfeccionamiento" del ser humano. ${ }^{21}$ Aparentemente, muchos de los izquierdistas de hoy han perdido el horizonte de que los bienes de este mundo están destinados para humanizar a toda la humanidad y no para ser apropiados privadamente por una minoría de ella. Incluidos en esos bienes el aire, el agua, los ríos, los mares, las playas, la biodiversidad, las entrañas de la tierra y el espacio sideral. Y como la pérdida de un horizonte lleva consigo la ganancia de otro, no pocos de estos líderes izquierdistas adoptan los mismos hábitos de consumo de lujo que solo pueden ser financiados por un capital privado continuamente creciente. Un ejemplo típico es el de los automóviles usados en este país por los diputados de la izquierda, que nada tienen que envidiar a los usados por los de la derecha. ¿Se pueden llevar y mostrar los signos de vida de los ricos impunemente sin ser asediados desde el corazón por el "humanismo" egoísta y acaparador de los ricos? "Donde está tu tesoro, allí estará también tu corazón". Hay una austeridad de vida 
que es propia de un ser humano nuevo desprendido de la posesión egoísta y entregado a la solidaridad compartida, capaz así de ir creando una nueva sociedad.

\section{Recuperar como realmente político el espacio cultural} de la privacidad. Eso implica la lucha contra el patriarcalismo, optando clara y decididamente por la liberación de las mujeres y por un trato social a ellas (en el trabajo sobre todo) que las equipare con los hombres, pero también controlando las pasiones dominantes de cada persona.

Muchos de nuestros simpatizantes, militantes y líderes izquierdistas piensan que la vida privada, y en concreto el modo como se configuren los hogares, no tiene nada que ver con la política. Si hemos leído atentamente los apuntes sobre "la crítica de la razón indolente" que expusimos en el primero de los retos, habremos captado que uno de los espacios donde se juega el poder es precisamente el espacio de las relaciones que conforman el hogar. Hablamos allá de una forma de poder que podemos caracterizar como patriarcalismo. Las relaciones del varón y la mujer en el hogar $-\mathrm{y}$ también las relaciones en otros modelos de hogar-y las que trascienden los límites del hogar y tienen lugar en el trabajo, profesional o de otro tipo, son cruciales para la nue- va sociedad que pretendemos. Un déspota patriarcal en el hogar tiene muy altas probabilidades de ser un déspota político en el movimiento social, en el partido o en el gobierno del Estado; de no permitir, por ejemplo, otro tipo de sindicalismo que el que se acomoda a ser cadena de transmisión de las consignas partidarias, ${ }^{22}$ en lugar de llegar a ser, en palabras de Ellacuría, una "tercera fuerza social". ${ }^{23}$ Una persona del género masculino que no se bata desde su mismo hogar por la liberación de las mujeres (su esposa y sus hijas, sus otras parientes y amigas), no se dará cuenta de que es importante que su partido articule claramente un programa de liberación e igualdad de la mujer en la vida pública. $Y$ alguien que - muy macho él- se permita varios amores libres fuera de su hogar o varios cambios semipermanentes de fidelidad marital, ¿Cómo va a transmitir credibilidad en su propuesta de fidelidad al pueblo de los pobres?

\section{Vincular estrechamente} la justicia, la libertad, la honradez, la recuperación del medio ambiente y de la seguridad ciudadana, y sobre todo la competencia al ejercer sus deberes, en sus programas políticos.

La pasión por la justicia ha sido siempre el sello de la izquierda social y política. El desarrollo de la historia en el siglo XX ha mostrado claramente que la justicia no fun- 
ciona sin la libertad. Es esta falta de pasión por la libertad la que hizo fracasar la así llamada "dictadura del proletariado". Los sujetos de la dictadura, por muy provenientes del proletariado que fueran algunos de ellos, nunca la transformaron en éticamente buena. La pasión por la libertad tiene en el ser humano raíces tan profundas como la pasión por la justicia. Con el programa de la dictadura, la historia nos ha mostrado que el proletariado se adelgaza hasta constituirse en la vanguardia del proletariado, la vanguardia se adelgaza hasta constituirse en el Comité Central del partido, el Comité Central se adelgaza hasta establecerse como Buró Político y el Buró Político se adelgaza hasta denominarse Stalin, Mao o Fidel.

Pero ni la pasión por la justicia unida a la pasión por la libertad valen del todo sin la pasión por la honradez con la realidad; distorsionar la realidad para adecuarla a la imaginación o al deseo políticos lleva a desengaños mortales, porque matan la capacidad de entrega al cambio necesario que hay que ir construyendo artesanalmente en la realidad. $\mathrm{Y}$ todas las pasiones políticas que hemos enumerado valen muy poco si no reconocen a la tierra y a sus entrañas, al aire y al agua, lo mismo que a la biodiversidad el respeto que se le debe al seno maternal donde se va formando la humanidad; justicia, libertad y honradez con la realidad — sin olvidar el entorno de la humani- dad- son pasiones necesarias para una nueva sociedad. Pero, a su vez, todas ellas se hunden si les falta la pasión por la competencia para desempeñar un cargo responsablemente; la incompetencia es el principio de la corrupción, la madre de todas las corrupciones; sin pasión por la competencia, alimentada por la formación continua y permanente, no hay acción política que haga otra cosa que no sea repetir la historia. Estas son las actitudes humanas que han de alimentar el sentido común, ese sentido común del que hablaba Gransci como componente fundamental de una cultura hegemónica, y del que habla Santos como "sentido común nuevo y emancipador".

\section{Saber y querer favorecer los relevos intergeneracionales para los puestos de dirección de las organizaciones sociales y políticas, así como para las candidaturas en los diversos poderes sometidos a elección.}

Pocos ancianos han sido modelos de pasión política humanizante. Los que lo han sido es porque han llegado a la cumbre de la autoridad ya en su ancianidad: en África, Nelson "Madiba" Mandela; en Europa, Konrad Adenauer; en Asia, Den Xiaoping; en América Latina, José Mujica. Los movimientos de izquierda y las personas que los lideran tienen la costumbre nefasta de perpetuarse en el poder, que no en la autoridad. Piensan que solo ellos pueden transmitir la ideología 
y el arte de gobernar con fidelidad a los principios revolucionarios. Al final, los principios revolucionarios se vuelven estrecha y rigurosamente reguladores y dejan de ser emancipadores. Reproducen los peores fracasos del pasado y son incapaces de reinventar el pasado conjurando el inconformismo de los antiguos luchadores y de las víctimas de la historia. Se vuelven plantas secas y arrugadas incapaces de diseñar un presente distinto del que ellos gozan y del que abusan. En el fondo, se aferran al hábito burocrático del poder, al tesoro económico empresarial — los fondos y los negocios del partido- y a los cuadros de los héroes colgados de la pared en la sede del partido. Les falta fe en el presente. Viven del pasado momificado y ya no son capaces de imaginar un futuro no repetitivo, es decir realmente nuevo, que pase por un presente nuevo. Las izquierdas políticas no tienen futuro si no se dan cuenta de que en política no basta el ADN confiable, sino que es indispensable la imaginación creativa. No basta el recurso a los héroes sin que a la vez sea memoria del inconformismo de los luchadores que quedaron sembrados en el campo de la historia como víctimas que claman al cielo. Y esa memoria es propiedad, habitualmente, de los relevos generacionales, sobre todo de los rebeldes.

\section{Combatir el divisionismo de la izquierda (uno de los factores que facilitaron, por}

\begin{abstract}
ejemplo, el derrocamiento de Salvador Allende en 1973 en Chile); construir la democracia interna en sus organizaciones sociales y políticas; organizar el disenso como debate permanente; reconciliar a las diversas corrientes construyendo puentes.
\end{abstract}

Uno de los problemas más difíciles de resolver en la izquierda política es admitir que su dirigencia no puede querer estar siempre en lo cierto por medios organizativos, inevitablemente bastante reguladores. La dirigencia de la izquierda política es uno de los grupos sociales donde más se cumple aquello de que "o estás conmigo o estás contra mí". Esto se cumple no solo en los partidos revolucionarios que más han conservado sus genes marxistas, sino también en los partidos social demócratas.

Un buen ejemplo fue, en la Alemania de comienzos del milenio, la incapacidad del SPD de conservar en su seno a Oskar Lafontaine y a su corriente más radical, que no veía futuro en la "Tercera Vía" del entonces canciller Gerhard Schröder. Y, asimismo, la dificultad de Oskar Lafontaine de domeñar su personalismo y fundir su indudable liderazgo con la inevitable disciplina partidaria para apropiarse ahí de las posibilidades históricas de triunfo futuro de su corriente radical. Aliada hoy esta corriente con los restos del Partido Comunista de Alemania Oriental, 
en una minoría -Die Linke- que apenas llega al 10\% del electorado, parece dejar pasar de largo esas posibilidades históricas de hacer fermentar la izquierda política alemana. El ejemplo chileno, que ya mencioné arriba en la formulación de este reto, fue no solo políticamente imprudente, sino sobre todo dramáticamente facilitador del golpe de Estado contra la democracia en Chile.

Pero también en El Salvador hay ejemplos históricos, como la retirada de la corriente social demócratacristiano demócrata, conocida antes como la Resistencia Nacional, del FMLN, muy forzada por el protagonismo de Joaquín Villalobos y Guadalupe Martínez, y la retirada de la corriente renovadora, luego Movimiento Renovador, que llevó a Facundo Guardado como candidato presidencial, perdedor frente a Francisco Flórez. En cambio, es importante que se haya mantenido dentro del FMLN la "Fuerza por el Cambio", con la que el alcalde de Santa Tecla por 4 períodos, Oscar Ortiz, disputó la elección para ser candidato presidencial del FMLN y la perdió contra Shafick Jorge Handal. Hoy, Oscar Ortiz es candidato vicepresidencial del FMLN en la fórmula que encabeza Salvador Sánchez Cerén.

El objetivo político en la izquierda no debería ser arrinconar a las formas de pensar disidentes, sino tender puentes con ellas para enriquecer a toda la izquierda. Eso significa abandonar el famoso "centralismo democrático", una opción política que nada tiene de democrática, y fundar la democracia interna en el organismo partidario, para que las diversas tendencias tengan la oportunidad de ser vistas todas ellas como contribuciones a la creación del conocimiento emancipador y no caigan víctimas del conocimiento regulador, es decir de la raíz del despotismo y/o dictadura que, desde la Revolución Francesa, ha abortado las mejores semillas del liberalismo de derecha y de izquierda. ${ }^{24}$ Todavía más, eso significa reconocer que cualquier tipo de dictadura es incompatible con la pasión humanista por la libertad humanizadora.

\section{Confrontar en serio la} secularización y la laicidad positiva del Estado con las fuentes pluralistas de legitimidad moral y espiritual de la convivencia, incluidas las religiosas, que en forma católica o evangélica son patrimonio de mucha parte del pueblo centroamericano. Dejar de mirar por encima del hombro a la religión, y combatir la utilización política de la religión, de derecha o de izquierda.

En su discurso inaugural como presidente de la República, Mauricio Funes, quien había encabezado la candidatura del FMLN, puso su presidencia bajo el modelo de 
preocupaciones de monseñor Oscar Arnulfo Romero: la opción por los pobres. Cinco meses después, otorgó póstumamente a los 6 jesuitas de la UCA —asesinados en 1989 por el ejército de El Salvador- la más alta condecoración del Estado, la Gran Cruz de la Orden Nacional de José Matías Delgado. El 24 de marzo de 2010, trigésimo aniversario del asesinato del arzobispo de San Salvador, Oscar Arnulfo Romero, el presidente Funes develó un mural dedicado a la vida y muerte de Monseñor en el aeropuerto de Comalapa que sirve a la capital. Días antes presidió en el Auditorio mayor de la Feria Internacional de San Salvador un concierto en honor de monseñor Romero. Y en el año de 2013, inauguró el mismo presidente una gran autopista que comunica la salida de la capital hacia Occidente con el Bulevar de los Próceres y la autopista hacia el aeropuerto, así como la que conduce al centro de la capital. En el proyecto inicial, esta autopista llevaba el nombre de Diego de Olguín; el presidente la bautizó como Autopista Monseñor Oscar Romero. Es curioso que El Diario de Hoy, el medio de prensa más conservador del país, siga refiriéndose a ella con su antiguo nombre.

El Estado salvadoreño es constitucionalmente laico. Estos actos del presidente Funes son un ejemplo de lo que queremos decir cuando hablamos de que la izquierda debe renovar su programa para entablar un diálogo fecundo entre las mejo- res formulaciones de las raíces en la secularidad o la laicidad y los mejores horizontes de las confesiones religiosas. El presidente Funes realizó en febrero de 2012 otro acto de parecido alcance: se hizo presente en el Mozote en el 30 aniversario de la gran masacre de El Mozote y, mientras honraba a las víctimas, rechazó la denominación de héroes para los miembros del ejército responsables de tales monstruosidades; incluso ordenó que se deben retirar de ciertos cuarteles y articulaciones del ejército los nombres de tales presuntos héroes. Desgraciadamente no fue obedecido por el ministro de Defensa, más aún fue explícitamente contradicho, una actitud que en no pocos países habría significado la destitución inmediata del ministro. Falta aún que el Estado cumpla con la sentencia de la Corte Interamericana de Derechos Humanos sobre el Mozote. No es fácil este diálogo de valores humanos que la izquierda debería asumir sin ambages como un diálogo serio entre raíces y opciones. Ni es fácil Ilevar a políticas de Estado uno de esos valores, talvez el principal, la opción por los pobres.

\section{Afrontar la articulación más eficaz y a la vez más justa entre el mercado y el Estado, entre la iniciativa privada y la planeación e inversión social del Estado.}

La izquierda arrastra como una de sus opciones principales la estatización de la iniciativa económica, 
fundamentalmente por medio de la planificación. La historia de la Unión Soviética ha mostrado claramente que ese es un callejón sin salida, además de poder convertirse en una senda de crímenes, tanto a través de la expropiación forzosa de los campesinos medianos en la agricultura, como también a través de la creación del no menos criminal medio de producción concentracionario (los campos de concentración dedicados al trabajo forzado de personas condenadas al exilio interno en su propia patria).

El keynesianismo mostró, sin embargo, cómo es posible optar por la intervención del Estado en la economía para encaminar a la población hacia el bienestar; y esto a través de leyes que legislan el seguro, obligatorio para los empresarios, de obreros y empleados; un sistema de impuestos progresivos que tienda a mantener la desigualdad de los ingresos entre parámetros relativamente aceptables; un sistema de contratos colectivos que den a obreros industriales y agrícolas y a empleados la posibilidad de verdaderos salarios familiares; una política monetaria que permita abordar los juegos especulativos de los inversionistas con cierto margen de seguridad ni inflacionaria ni deflacionaria, etc. El primer periodo presidencial de François Mitterrand como presidente de la República Francesa en los años ochenta mostró la posibilidad de articular con la libre iniciativa privada un plan estatal de inversiones nacionales y de propiedad y administración de ciertas industrias demasiado estratégicas como para quedar enteramente en manos de la iniciativa privada. Los años entre 1945, final de la Segunda Guerra Mundial, y 1975, afianciamiento de la crisis petrolera, mostraron la posibilidad de regular la economía sin estatizarla - este tipo de opción reguladora era en realidad emancipadora-.

Desde entonces, la desregulación de los mercados; la globalización de la industria en búsqueda de obreros que exijan menor retribución salarial; la conversión en dogma de que el keynesianismo es ruinoso para los Estados cuando se combina con una curva demográfica que cada vez desequilibra más las edades a favor de jubilados, retirados y ancianos; la doctrina de que solo las fuerzas laborales han de ser intervenidas para contraer sus salarios sin que se intervengan los siempre crecientes ingresos del capital privado; y la conversión de las finanzas en un casino global, cuyas pérdidas tienen que ser después compensadas por fondos provenientes del Estado, es decir de los impuestos, han quebrado por el momento las expectativas levantadas por el keynesianismo. Toca a las izquierdas adentrarse por los caminos de investigación y de puesta en práctica de una articulación entre mercado y Estado que resulte humanizadora y no deshumanizante, sabiendo que tiene en contra todo 
el rumbo actual de la economía dominante en el mundo, y que, sin embargo, los años de Lula en Brasil y del Frente Unido en Uruguay, así como la dirección fundamental de los gobiernos de Correa en Ecuador y de Morales en Bolivia muestran posibilidades históricas esperanzadoras.

\section{Insertarse en la globalización} favoreciendo como un paso absolutamente necesario la integración centroamericana (SICA) y su vinculación con los diversos focos de cooperación latinoamericana (MERCOSUR, UNASUR, Comunidad Andina, ALBA, CARICOM, Grupo de Río, Confederación del Pacífico, etc.) para tratar de negociar desde la unidad latinoamericana con los otros focos internacionales.

Es poco probable que América Latina pueda ser interlocutora seria y relativamente autónoma en el concierto mundial si no logra hablar y negociar con una sola voz. Desde Centroamérica, la izquierda política tiene una tarea fundamental: dejar de jugar con la integración centroamericana. Únicamente países centroamericanos que no solo permitan, sino que favorezcan el movimiento libre de personas a través de sus fronteras, pueden pensar en ir construyendo un istmo más influyente en los asuntos latinoamericanos y contribuir a la superación de esa fuente de poder que es "el intercambio desigual".

Sin embargo, es muy difícil llegar a esta mayor unificación y poder de interlocución mientras los gobiernos no tengan la valentía de liderar la apertura de las culturas nacionales, por ejemplo fomentando en Costa Rica la solidaridad con sus vecinos y en Guatemala combatiendo el racismo interno contra los indígenas. La insolidaridad costarricense, producto del "nosotros somos diferentes y no podemos centroamericarnos", y el racismo guatemalteco, que no puede ni siquiera reconocerse como tal, son modelos terribles de caminos autosuficientes condenados al aislamiento.

Una de las grandes riquezas que empieza a redescubrirse en América Latina, la riqueza dependiente de la extracción, bien sea minera, de gas o petrolera, significa una fuerza de contradicción. Hay países, como Perú, totalmente volcados a una política estatal de extracción, hay países como El Salvador que se atreven a declarar una moratoria en la extracción y países como Costa Rica que legislan en contra de la minería a cielo abierto. No se ve claro que los gobernantes en América Latina recojan el desafío del proyecto bolivariano (que no tiene únicamente el rostro de Chávez). Sin mayor unidad latinoamericana no será posible ser una fuerza de interlocución global a partir de los intereses de las grandes mayorías. 


\section{Afrontar la violencia como problema interno y global.}

La izquierda política debe asumir la violencia como una situación social en la que ella misma tiene responsabilidad en la medida en que su utilización de las armas no ha sido sometida a una interna comisión de la verdad. Quiero decir, a una comisión que sea capaz de volver la mirada con ecuanimidad sobre las decisiones que condujeron de su parte a la guerra y no solo sobre las decisiones de la derecha que llevaron a ella, pero sabiendo también que la violencia en nuestra región centroamericana entierra sus raíces en la conquista y en la reforma liberal, una de cuyas últimas manifestaciones fue la masacre de 1932. La violencia es centenaria, no es de hoy. Por consiguiente, no ayuda para nada tomar ante ella posturas histéricas o unilateralmente acusadoras. Además, la violencia tiene hoy fuentes globales, especialmente en las industrias y comercios prohibidos, que son el rostro de un capitalismo sin ley: las industrias y los tráficos de narcóticos, de armas, de la prostitución internacional, de órganos, de la adopción internacional, de desechos nucleares, etc. Una de las fuentes mayores de violencia está en la región amazóni$\mathrm{ca}$, donde hacendados y madereros destrozan cada vez mayor extensión de la cobertura forestal de la selva, amenazando la reserva mayor de agua del mundo. Esta reserva, sobre la que los Estados Unidos tienen siempre una mirada vigilante, supone un corredor para su transporte hacia el Norte, que afecta a Centroamérica y México directamente, pero en realidad a todos los países amazónicos. Luchar por la preservación de esta reserva debe ser uno de los más importantes programas políticos de la izquierda.

\section{El reto último y, a mi juicio, tal vez el más fundamental, de la izquierda es ayudar a hacer salir de la pobreza a la gente que sufre bajo esa plaga.}

La inversión pública habría de ir destinada principalmente a este objetivo. Se puede decir que una de las razones fundamentales por las que el presidente Lula ganó las elecciones para un segundo periodo con un $60 \%$ de los votos fue porque uno de los resultados de su primer periodo había sido ayudar a salir de la pobreza a 20 millones de brasileños y brasileñas. Y la continuación de estos programas siguió siendo una de las razones por las que mantuvo su ranking de aprobación en un $80 \%$ y facilitó la elección de su sucesora, Dilma Roussef.

En la lucha para que los pobres salgan de la pobreza se combate para ayudar a romper el actual apartheid económico global que, como aquel de Sudáfrica, se fundamenta en el racismo. El racismo es la raíz más perversa, y probablemente más arraigada, de la civilización occi- 
dental. Es la conciencia de superioridad de los ricos y de quienes en ellos se miran como en un espejo de sus expectativas, la que lleva a tomar la opción de que la pobreza no importa, más aún, que es culpa de las poblaciones empobrecidas, que serían humanamente inferiores. Pero es imprescindible llevar adelante esta lucha humanamente, con un materialismo humanista (parte de una auténtica espirituali- dad), que tenga como finalidad la opción de responder urgentemente a las necesidades fundamentales de los más de ciento cincuenta millones de pobres del continente, entre ellos los nuestros centroamericanos, y ponga al mismo tiempo los cimientos para una valoración no consumista de la vida, para un dejar de ser pobres que no conlleve mayoritariamente el deseo de llegar a ser ricos insolidarios.

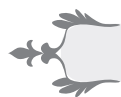

No es posible ser de izquierdas sin repensar el mundo; y tampoco sin tener voluntad política de un cambio de estructuras. $Y$ no es posible tampoco ser de izquierdas sin tener voluntad política de un cambio en los corazones y en la práctica de las personas. Difícilmente será de izquierda en la práctica quien conciba el avance de la sociedad o progreso como alcance de la misma forma de riqueza que caracteriza al capitalismo. Sabemos cómo Ignacio Ellacuría empleó el aforismo kantiano de que lo voluntario que no puede ser "principio de una legislación universal" tampoco puede ser moral, y ni siquiera humano: "El ideal práctico de la civilización occidental no es universalizable, ni siquiera materialmente, por cuanto no hay recursos materiales en la tierra" que permitan a más del $75 \%$ de la humanidad vivir como lo hace menos del $25 \%$ de ella. ${ }^{25}$
Difícilmente será de izquierda en la práctica quien personalmente y en su familia se haya adentrado por las rutas del "fetichismo de las mercancías", que hoy Ilamamos más suave y comprensiblemente consumismo (presente en el barrio donde aspira a vivir, en la casa que aspira a comprar, alquilar o construir, en la marca de carro que aspira a manejar, en los juguetes electrónicos que aspira a comprar para sus hijos e hijas, etc., etc.). $\mathrm{O}$ difícilmente será de izquierda una persona que le es infiel a su pareja, mucho más si anda pasando la vida de pareja en pareja. Porque, ¿no será bien difícil ser fiel a la gente pobre si no se puede ser fiel a la propia pareja? Obviamente no se trata de juzgar aquí las incompatibilidades que pueden llevar a la separación. No se trata de moralismos, sino de estructuras humanas y humanizadoras de la personalidad, 
en las cuales se enraíce la voluntad de estructuras sociales nuevas.

Así podremos celebrar la profunda afirmación de que "otro mundo es posible", luchando por una relación mucho más seria entre las raíces de la fraternidad y la igualdad con las opciones por la justicia y la libertad, o mejor por la liberación, que incluye las dos y tiene la aspiración de convertirlas en raíces universalmente humanas.

Notas

1 Schweickart, David, Más allá del Capitalismo, Santander, Sal Terrae, 1993.

2 Fossaert, Robert, L'Avenir du Socialisme, Paris, Stock, 1996.

3 Castells, Manuel, La Era de la Información, I "La sociedad red", 1996 (en inglés) y 1999 (en castellano); II "El poder de la identidad”, 1997 (en inglés) y 1999 (en castellano); III "Fin de milenio", 1998 (en inglés) y 1999 (en castellano); México, Siglo XXI editores.

4 Dagnino, E., Olvera, A..J. y Panfichi, A., A disputa pela construsao democrática na América Latina, Sâo Paulo, Paz e Terra, 2006.

5 Santos, Boaventura de Sousa, Crítica de la razón indolente: Contra el desperdicio de la experiencia, Bilbao, Desclée, 2003, pp. 77-78. En adelante citaré SC y página en el texto.

6 Un conocedor de la ciencia actual, familiarizado con mi artículo, escribe estas palabras: "Al llegar los avances tecnológicos a la nano escala, en donde las propiedades de los materiales y leyes físicas conocidas ya no se aplican, se llega al punto de máxima incertidumbre. Ahora, se abre la posibilidad de un nuevo comienzo para la ciencia y muy distante de considerar a la naturaleza como un autómata. El nuevo conocimiento científico más bien parece una superficie con muy pocos lugares seguros de estabilización y muchas trayectorias

7 Para los conocedores de Nietzsche, ya este filósofo lo entendió así.

8 La tecnología, por ejemplo en el campo de la comunicación electrónica, propone como paso gigante de la humanidad actual el tránsito de un modelo $W$ indows a otro Apple, cuando habitualmente solo se trata de mejoras comercialmente competitivas en modelos que pueden siempre superarse mutuamente. Otra cosa es el humanismo de la ciencia y los científicos, que saben bien lo cerca que están, en sus hallazgos, de las "mitologías" de la humanidad.

9 Una resonancia práctica la tenemos obviamente en el "utopismo automático de la tecnología" de la así llamada "minería verde", contra la cual oponemos el coraje de temer las consecuencias negativas de la minería para la ecología y para la salud humana, así como para la destrucción de comunidades. 
10 Es difícil exagerar la importancia de esta manera de recrear la superación de la modernidad. El individualismo es inseparable de la modernidad, y arrastra a las personas hacia la soledad competitiva. En el Ensayo sobre la ceguera, Saramago da forma poética a esta soledad, competitiva hasta la violencia y el exterminio, de la condición humana moderna.

11 Arendt, Hannah, Beyond Past and Future, Cleveland, Meridian Books, 1963, p. 149. Citada por Santos.

12 Es esclarecedor cómo esta definición ha servido como anillo al dedo al poder central eclesiástico del Vaticano, es decir, del Papado, intermediado por la burocracia de la Curia Romana. Algo que choca con aquel "no sea así entre ustedes", que Jesús de Nazaret marcó como prescripción fundamental para la autoridad en la comunidad de sus seguidores. Y que el papa Francisco parece querer reformar.

13 Santos, Boaventura De Sousa, El milenio buérfano. Ensayos para una nueva cultura politica, Madrid, Trotta, 2005, pp.117-118. En adelante citaré (SM y la página).

14 Wallerstein, Immanuel, Geopolitics and Geoculture, Cambridge, Cambridge University Press, 1991. Ver Prólogo.

15 Las matrices sociales consideran la compleja variación de muchos factores interdependientes que ocasionan un probable resultado, por ejemplo una elevada incidencia de muertes al nacer. Mientras que las mediatrices (como lo indica su concepto geométrico de rectas que cruzan por el punto medio entre dos extremos) apenas consideran el resultado de la comparación entre dos extremos, por ejemplo, la diferencia de mortalidad al nacer entre el 1\% más rico y el $20 \%$ más pobre de la población en un país.

16 A nivel epistemológico, el colonialismo es una metáfora tomada del campo político. Se puede colonizar el conoci- miento, haciendo aparecer la rebelión únicamente como caos, y la solidaridad como ingenuidad. Quien coloniza es el conocimiento regulador. $\mathrm{Y}$ es el conocimiento emancipador el colonizado.

17 "La parábola de la tragedia de los comunes" fue un escrito de Garrett Hardin, publicado en Science, vol. 162, n. 3859 , December 13, 1968, pp. 12431248 [Obtenido visitando Wikipedia, Tragedia de los Comunes]. Preocupado por el incremento poblacional, Hardin describe el caso en que una serie de individuos en prosecución de su interés individual acaban por destruir el recurso común que todos igualmente pretenden. Entre nosotros, el bosque o el agua pueden ser buenos ejemplos de la tragedia.

18 Puede verse en el sitio google "Ira Rennert mansion".

19 Así se escuchaba hablar al general sandinista Humberto Ortega en un video de un periodista mexicano.

20 Stiglitz, Joseph, El precio de la desigualdad, Madrid, Taurus, 2012, p. 31. El 1\% de la población tiene lo que el $99 \%$ necesita.

21 Ellacuría, Ignacio, "Utopía y profetismo", en Ellacuría, Ignacio y Jon Sobrino, Mysterium Liberationis. Conceptos fundamentales de la teología de la liberación, Madrid, Trotta, 1990, Vol. I, pp. 426427.

22 Ellacuría, Ignacio, "La cuestión de las masas", en Veinte años de historia en El Salvador (1969-1989). Escritos Políticos, San Salvador, UCA Editores, 1993, pp. 777-798.

23 Ellacuría, Ignacio, "La Constitución de una tercera fuerza social", en Veinte..., op.cit., pp. 1127-1138.

24 Wallerstein..., Geopolitics...op.cit., ibid.

25 Ellacuría..., “Utopía...", en Mysterium..., op.cit., pp. 406-407. 